\title{
What is IUGS?
}

\section{What is IUGS?}

The International Union of Geological Sciences (IUGS) is one of the largest and most active scientific associations in the world. A voluntary professional organization, it is nongovernmental, non-political and non-profit-making. It aims to

- encourage the study of geoscientific problems, particularly those of worldwide significance.

- facilitate international and interdisciplinary cooperation in geology and its related sciences;

- provide continuity to such cooperation, and

- support and provide scientific sponsorship to the quadrennial International Geological Congress (IGC).

How did it originate?

The Union was founded in March 1961, in response to a need to coordinate international geoscientific research programs on a continuing basis. Geoscientists felt that a mechanism was required to take action on global geological problems between the International Geological Congresses, traditionally held every four years.

IUGS was also to serve as a vital link in solving problems requiring interdisciplinary input from other international scientific unions operating under the aegis of the International Council of Scientific Unions. Compared to these, IUGS was a "latecomer," although some of its responsibilities had been carried out by the International Geological Congress - a venerable institution over a century old.

Since 1961, IUGS has experienced rapid growth in membership, scientific scope and expertise, as well as international prestige.

\section{What does it do?}

IUGS fosters communication among the various specialists in earth sciences around the world. It achieves this by organizing international projects and meetings, sponsoring symposia and scientific field trips, and producing publications.

Topics addressed range from fundamental research to its economic and industrial applications, from scientific, environmental and social issues to educational and developmental problems. For example, IUGS is currently involved in

* working toward international agreement on nomenclature and classification of stratigraphical units,

* storing, retrieving and processing geological information,

* supporting efforts to harmonize human societies with their environment,

* establishing systematic nomenclature in petrology,

* applying results in remote sensing to geology,

* studying planetary geology and its relevance to the understanding of earth history,

* assessing the geology of the ocean basins and their economic potential,

* elucidating the nature, dynamics, origin and evolution of the Earth's deep crust,

* studying mineral deposits to aid future exploration efforts.

\section{Who carries out IUGS' scientific work?}

The Union has several standing Commissions dedicated to studying a particular geological field, methodology or problem. At present, IUGS Commissions include the

* Commission on Comparative Planetology,

* Commission on Geological Documentation,

* Commission on Geology Teaching,

* Commission on Global Sedimentary Geology,

* Commission on the History of Geological Sciences,

* Commission on Igneous and Metamorphic Petrogenesis,

* Commission on Marine Geology,

* Commission on Storage, Automatic Processing and Retrieval of Geological Data,

* International Commission on Stratigraphy,

* Commission on Systematics in Petrology,

* Commission on Tectonies,

* Commission on Fossil Fuels (to be confirmed).

Commissions vary in size, though each is composed of a suitable number of geographically representative experts. Some are subdivided into Subcommissions, Regional Committees or Working Groups according to the specific tasks charged to them. Much of the work of the Commissions is done by correspondence.

Committees, task groups or working groups carry out short-term or temporary assignments, often to determine the extent of IUGS effort required in areas not covered by Commissions or associations affiliated to IUGS. Advisory Boards provide expert advice to the Executive Committee, convene meetings, conduct reviews, and prepare reports and recommendations, generally on an annual basis.

The Advisory Board for Research Development is a group of widely recognized scientific experts and successful managers of major scientific programs in industry, and in

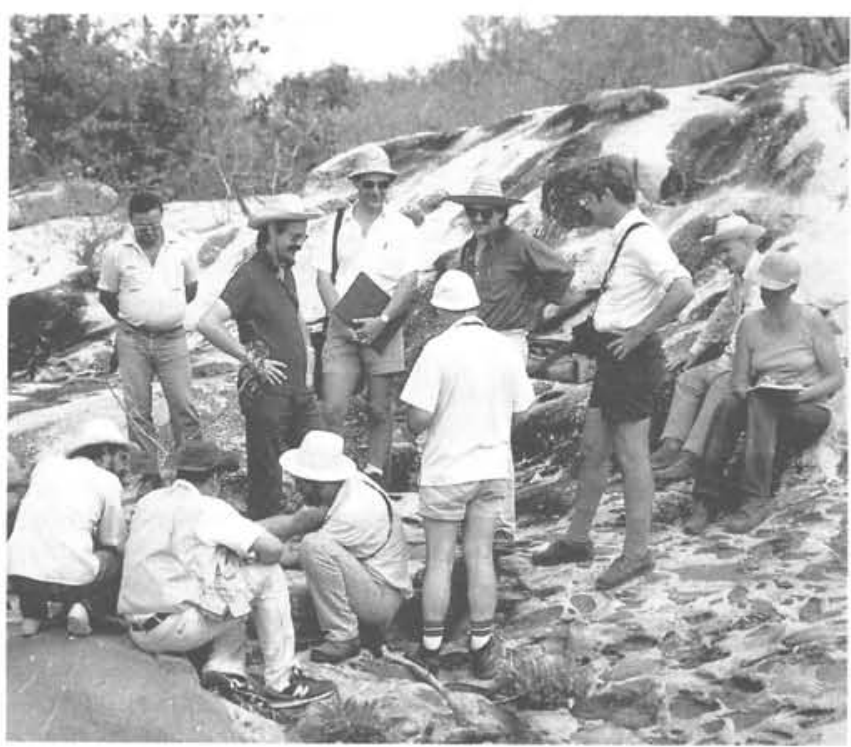

Figure 1. Geologists examine a granite outcrop in northern Brazil. 


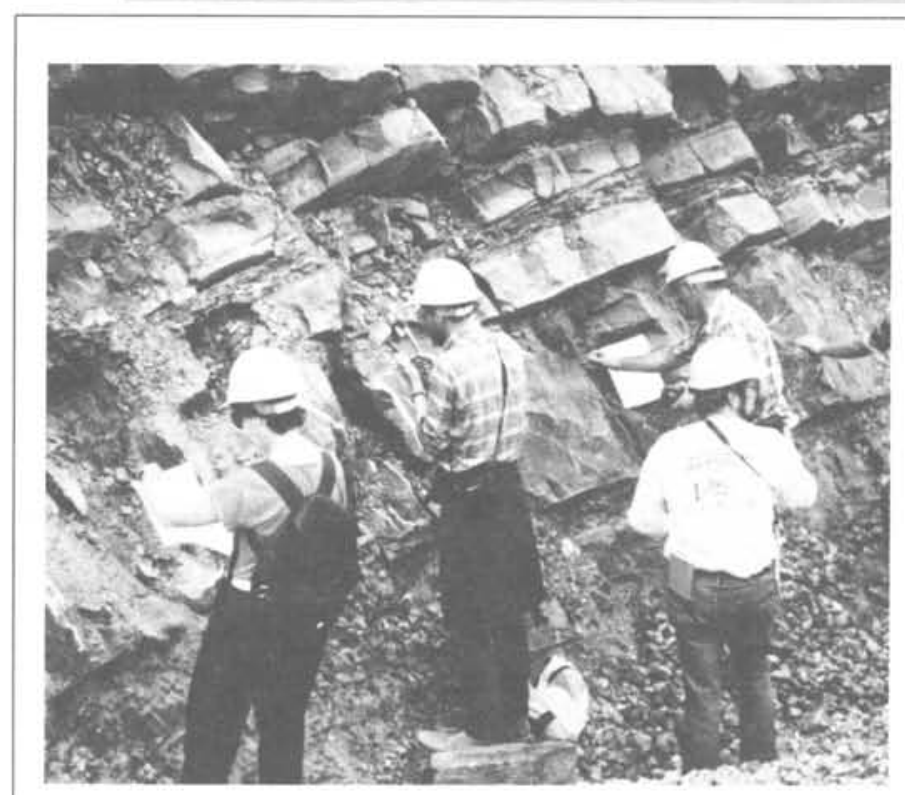

Figure 2. Stratigraphy constitutes a major focus in the research work undertaken by some of the Commissions and Subcommissions. Here,

biostratigraphers examine Visean strata in SW England.

governmental or academic sectors. This Board reviews IUGS scientific activities and recommends re-direction of effort in programs or projects, initiation of new activities, or formulation of future research themes to assist in longer term program planning. The Board also makes recommendations on overall science management issues, and on funding levels necessary to support research projects (see Rutland, this issue).

The Advisory Board on Publications provides recommendations on issues concerning IUGS publishing activities, it coordinates the various publications series, examines applications for publications and advises the Executive Committee on publication standards and techniques (see IUGS Publication Policy, this issue).

In addition IUGS has currently an Advisory Board on Remote Sensing.

\section{Scientific Work of IUGS}

A major part of IUGS effort goes into multidisciplinary international Joint Programs, sponsored by IUGS and other organizations.

The International Geological Correlation Programme (IGCP) is co-sponsored by the intergovernmental United Nations Educational, Scientific and Cultural Organization (Unesco) and IUGS. A unique and successful collaborative venture operating since 1972, IGCP works worldwide to organize and distribute knowledge about geological resources and environment. Specifically, it aims to refine and calibrate methods used in correlating geological relationships and events, analyze the processes involved in major mountain-building orogenies, and understand the formation and occurrence of mineral deposits in relation to such episodes. About 50 research projects involving hundreds of participants are currently operating under the auspices of the IGCP (see e.g. Chumakov and Elston, this issue), and over 40,000 publications have resulted from the various projects.

The Inter-Union Commission on the Lithosphere (ICL) coordinates the research-oriented International Lithosphere Program, co-sponsored by the International Union of Geodesy and Geophysies (IUGG), the International Council of Scientific Unions (ICSU) and IUGS. Building on the scientific achievements and multidisciplinary cooperation of the successful International Geodynamics Project, ILP addresses some of the crucial scientific challenges of the $1990 \mathrm{~s}$ (see Zwart, this issue). The ILP focusses on the dynamics, origin and evolution of the Earth's deep crust and upper mantle (lithosphere) and pays special attention to the continents and their margins. Results will aid in assessing, predicting and mitigating geological hazards, both of natural origin (such as volcanic eruptions) and those induced by man (such as landslides).

\section{Other Cooperative Enterprises}

The successor to a highly successful IGCP Project on remote sensing, the Geological Applications of Remote Sensing (GARS) Program was launched by IUGS and Unesco in February 1984. GARS promotes the dissemination of remote sensing concepts and techniques to less developed areas of the world, through demonstrations, training onsite, collaborative research, and providing information useful to local efforts (see Gabert, this issue).

The IUGS/Unesco Deposit Modelling Program, organized in January 1984, is designed to advance geoscientific knowledge and expertise in mineral deposit modelling for use in exploration, assessment, and development of resources. It also facilitates the transfer of this knowledge and expertise to developing countries and assists in training and educating geoscientists from developing regions, so that they can carry out the necessary exploration and resource assessment in their home countries.

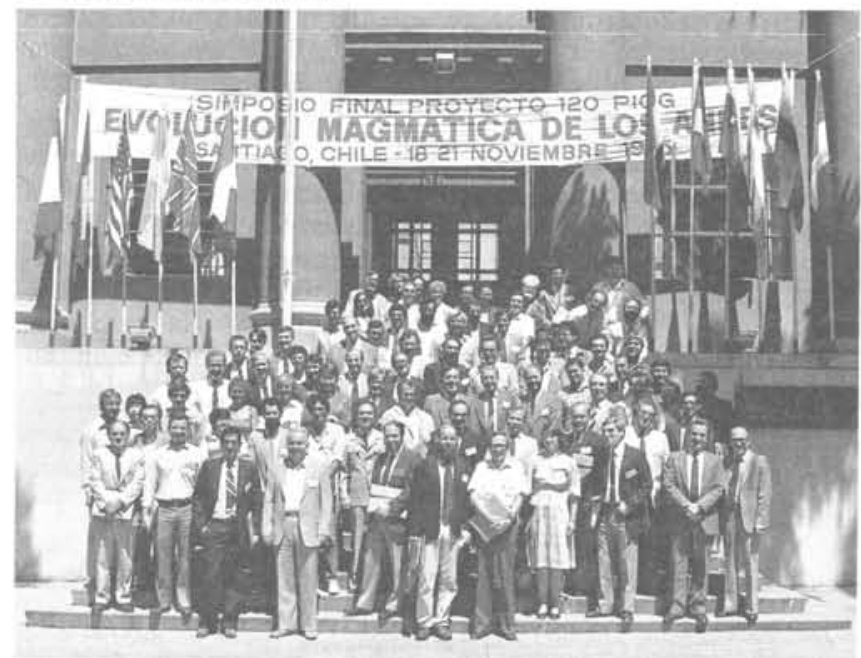

Figure 3. IGCP conference participants gathered in Chile to discuss Andean magmatism.

The Circum-Atlantic Project, cosponsored by the IUGS and the Commission for the Geological Map of the World, in cooperation with national and international organizations in the Atlantic region, is striving to organize, coordinate and stimulate the compilation and interpretation of geological, geophysical and resource data for the Atlantic seafloor and adjacent continental areas. The data will be used to compile and publish an integrated series of thematic maps and cross sections, and in pilot studies to experiment with applications of data for specific problems.

In recent years, acting on the advice of the IUGS Advisory Board for Research Development, the Union has succeeded in fostering a number of regional joint projects, including the productive East European effort that resulted in a Neogene Map Series of the Pannonian Basin, a study of the metallogenesis of mafic and ultramafic rocks in the CircumCaribbean, and a project in the Andes region of South America that established a data base on the extent, characteristics and controls for mineralization of tin and associated elements. Other joint ventures currently in the 
developmental stage include a project dedicated to the role of geoscience in resolving urban development problems, particularly in southeast Asia, a study of the fundamental contributions that the geosciences can bring to the ICSUsponsored Global Change program and to the UN-sponsored International Decade on Natural Hazards Reduction.

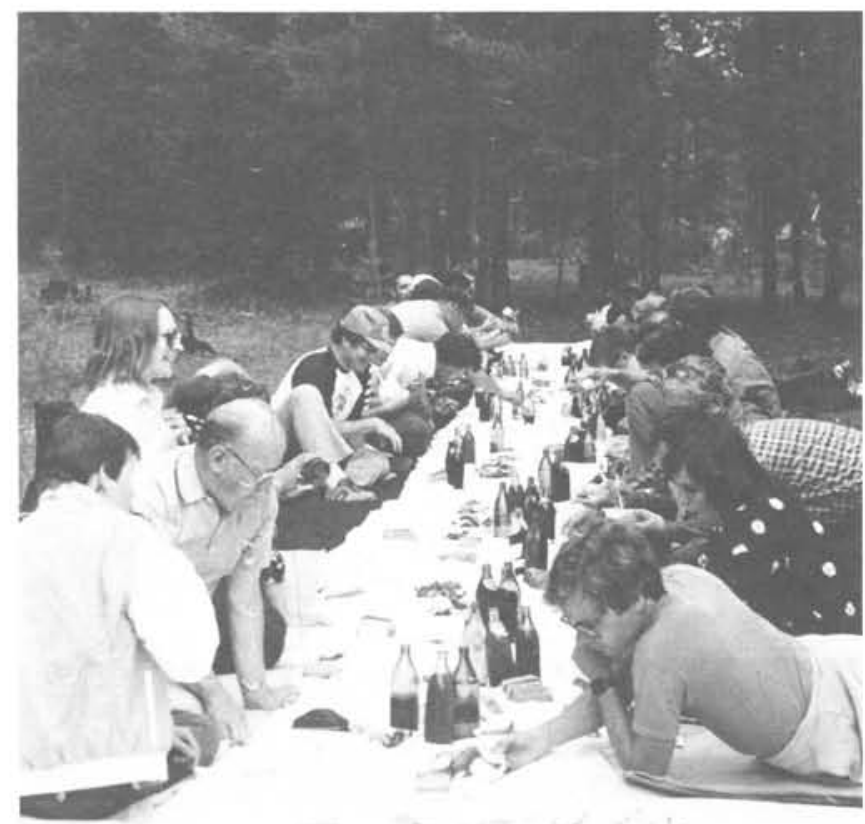

Figure 4. It is not uncommon in scientific circles to hear talk of the IUGS "family": personal dedication to Union activities testifies to the spirit of goodwill and sense of common purpose engendered by IUGS.

\section{Who are the members of IUGS?}

Membership in IUGS is open to countries (or defined geographical areas), generally through a designated "adhering organization," which may be a national committee or an appointed academy, geological survey or similar national agency.

Each adhering organization pays annual dues to IUGS according to its eategory of membership. Currently, dues are as follows:

\section{Category}

$\begin{array}{lllllllll}\text { Units* of Contribution } & 1 & 2 & 4 & 7 & 12 & 20 & 35 & 70\end{array}$

$$
\text { (i.e. dues) }
$$

* The value of a unit of contribution, set at $\$ 300$ (U.S.) in July 1980 , is currently being restructured.

Adhering organizations have the right to vote at IUGS Council meetings and thus control all major decisions affecting the Union. Between Council sessions, the Executive Committee maintains close ties with adhering organizations. They are regularly consulted on the scientific directions being pursued by the Union and kept informed of IUGS activities and their administration through complimentary copies of Episodes, the IUGS quarterly newsmagazine, and through copies of major reports and minutes of meetings.

Associate membership status in the Union entitles a member to information about IUGS activities commensurate with the amount of financial contribution made to the Union annually.

IUGS members, who now total 93, are listed on the inside front cover of this issue. Membership application forms are available on request from the IU GS Secretariat.

\section{Affiliated Organizations}

Special scientific interests and disciplines are represented in the Union through its Affiliated Organizations - that is, large autonomous international associations which share with IUGS an interest in planning and undertaking certain scientific activities and meetings of mutual benefit (e.g. see Boyle, this issue). A list of the affiliated organizations is given on the last page of this issue.

\section{Who is responsible for managing IUGS?}

The Council holds ultimate authority over IUGS activities. Composed of representatives of national adhering organizations, the Council usually meets every four years during the International Geological Congress to review the progress made by IUGS constituent bodies, the administration of the Union and its accounts, and to decide on any new proposals or initiatives. The Council has the power to institute or disband a Commission, change the value of a unit of contribution in membership dues, amend the IUGS constitution, and to dissolve the Union.

The overall management of Union activities is carried out by the Executive Committee, elected by Council on the recommendation of a Nominating Committee. Elected Executive Committee members include a President, a Past President, a Secretary-General, a Treasurer, and eight Vice Presidents, all of whom hold office between ordinary sessions of Council - that is, for four years, following which all of these officers (except the President and the Past President) are eligible for re-election. The current (June 1989) Executive Committee members are listed on the inside front cover of this issue of Episodes.

The Secretary General is appointed by the Executive Committee. To ensure continuity in administration, the Past Secretary General serves on the Committee in an ex-officio capacity for one year after the end of his term of of fice.

The Executive Committee normally meets annually and, as the executive arm of the Council, deals with the major policy, operational and administrative issues affecting the Union. The Executive consults on a regular basis with the IUGS Advisory Board for Research Development and other advisory groups.

The Bureau consists of the President, Treasurer and Secretary General and is responsible for the day-to-day operations of the Union. Bureau members maintain offices on behalf of the Union and a small staff to assist them.

\section{How is IUGS financed?}

The Union's chief sources of revenue are

- Membership dues;

- Unesco contracts for IGCP projects and funds from the Unesco subvention to ICSU;

- Revenues generated in support of multilateral or bilateral program activities;

- Special grants from ICSU;

- Income from sales of IUGS publications, royalties, and Episodes;

- National support to operate the IUGS Secretariat, the Episodes Secretariat, the Treasurer's Office and the President's Office from the respective host countries.

Officers of the Union serve without remuneration, and administrative costs are kept to a minimum. A Finance Committee, headed by the IUGS Treasurer, proposes the Union's annual budget and long-term financial plans and advises the Executive Committee on all financial matters. IUGS Financial Statements are published annually in Episodes.

\section{What does IU GS publish?}

IUGS publishes Episodes, its popular quarterly newsmagazine, which offers the latest information on IUGS and 
other international projects and programs, and which is available to anyone by subseription.

An IUGS publication series identifies and gives credit to some of the scientific activities carried out under the auspices of IUGS. Over 20 titles are available from the Episodes Secretariat.

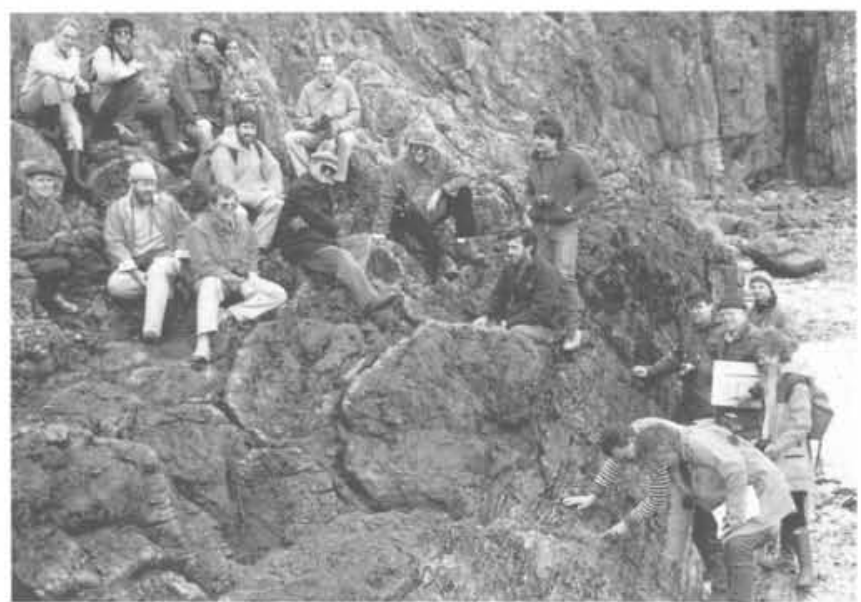

Figure 5. IUGS supports a variety of projects which aid regional economic development throughout the world. These conference participants are forming firsthand impressions of ancient volcanic rocks in Brittany, France.

What is the relationship between IUGS and the International Geological Congress?

In a sense, IUGS is both the "child" and the "godfather" of the International Geological Congress, the oldest and largest international gathering of geoseientists. When IUGS was established in 1961 , it was partly to provide continuity to the coordination effort that was required between Congress sessions. Today, the IUGS Executive, its Commissions and Affiliated Associations advise and assist the organizers of the Congress in formulating its scientific program, though the formidable task of organizing the Congress as a whole is the responsibility of - the national institutions of the country hosting the Congress. The Union thus provides scientific sponsorship to the Congress, an important forum for IUGS scientific results.

\section{What are some of IUGS' major accomplishments?}

As the broadest ranging international forum for the geological sciences, IUGS has established an effective and highly respected global network for communicating across disciplines, across political and geographical boundaries, across levels and gaps of knowledge.

This has led to countless examples of improved resolution of scientific problems, establishment of better standards and techniques, more enlightened definition of fields requiring future scientific enquiry - in short, the strengthening of the scientific base on which geological research rests and without which geoscience cannot be effectively applied toward improving human welfare.

A sample of some specific accomplishments conveys the variety and scope of IUGS initiatives:

* The Commission on Stratigraphy has guided the establishment of many global stratotypes, as summarized in the chart enclosed in this issue (and see article by Cowie, Ziegler and Remane).

* A collaborative project sponsored by IUGS has produced a palaeographic map series of the Neogene in central and eastern Europe - on a seale of $1: 1,000,000$.
* The first Geological Multilingual Thesaurus, a monumental contribution that has taken several years of collaborative effort by the IUGS Commission on Geological Documentation, now acts as a switching mechanism among existing databases in various countries.

* An IUGS symposium held recently in Brazil reviewed granites and their associated mineralizations.

* The Commission for the Geological Map of the World an IUGS affiliate - has recently published the Geological World Atlas in 22 sheets at a seale of $1: 10,000,000$, and geological, tectonic, metallogenic and metamorphic maps of most continents at a scale of $1: 5,000,000$. These are all vital tools for the working geologist.

* Another affiliate - the Association of Geoscientists for International Development - holds workshops each year in developing regions of the world on topical subjects such as urban geology, gemstones, global change and geological education.

* The Commission on Global Sedimentary Geology manages a world-wide program of which a major project is focussing on sedimentary rocks and processes of the Cretaceous Period.

* IUGS affiliates have organized in recent years the major international congresses and symposia on mineralogy, sedimentary, engineering geology, ore deposits, and many other topies.

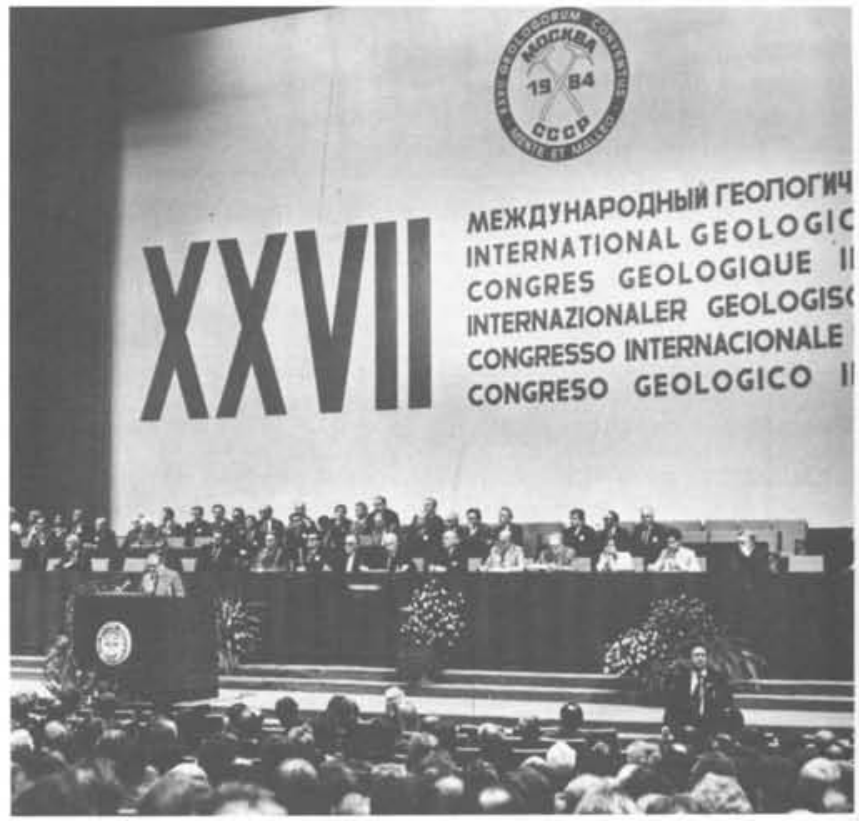

Figure 6. The International Geological Congress, traditionally held every four years and sponsored by IUGS, draws thousands of geologists from every corner of the world.

\section{Where can one get more information about IUGS?}

Both the IUGS Secretariat and the Episodes Secretariat (addresses are on the inside front cover) stock copies of the literature that is available on IUGS. This includes

- Complete lists of IUGS Publications, and many of the publications themselves;

- IUGS Statutes and By-laws;

- Brochures on IU GS, IGCP, and ICL;

- Episodes, as well as subscription and advertising information;

- IUGS Membership Application Forms. 